\title{
Elemental fingerprinting of fish otoliths using ID-ICPMS
}

\author{
Steven E. Campana', Jacques A. Gagné ${ }^{2}$, James W. McLaren ${ }^{3}$ \\ ${ }^{1}$ Marine Fish Division, Bedford Institute of Oceanography, PO Box 1006, Dartmouth, Nova Scotia, Canada B2Y 4A2 \\ ${ }^{2}$ Fisheries Oceanography, Maurice Lamontagne Institute, PO Box 1000, Mont Joli, Québec, Canada G5H 3Z4 \\ ${ }^{3}$ Institute for Environmental Research and Technology, National Research Council of Canada, Ottawa, Ontario, Canada K1A 0R6
}

\begin{abstract}
Trace elements incorporated into the growing surface of the fish otolith (ear stone) reflect the physical and chemical characteristics of the ambient water, although not necessarily in a simplistic manner. Since otoliths grow continuously without resorption throughout the life of the fish, fish populations growing up in different water masses should produce otoliths of different elemental composition. The otolith elemental composition ('fingerprint') determined with isotope dilution - inductively coupled plasma mass spectroscopy (ID-ICPMS) proved to be an effective discriminator of adjacent populations of Atlantic cod Gadus morhua off the coast of eastern Canada, with sufficient accuracy as a natural tag to determine population identity in a mixed population fishery. Classification of samples collected from the winter cod fishery on the eastern Scotian Shelf indicated that the annual winter migration out of the Gulf of St. Lawrence is more extensive than was previously believed.
\end{abstract}

KEY WORDS: Otolith · Composition - Trace elements · Migration · Stock identification - Population discrimination

\section{INTRODUCTION}

Measures of growth, survival, and reproductive success in marine fishes, as well as much of the basis of modern fisheries management, assume that a single population is being monitored. Unfortunately, there are few natural markers, whether genetic or morphological, which can be used to consistently differentiate among adjacent populations. Recent studies have pointed to the potential of the otoliths (ear stones), found in all fishes, as natural population markers (Edmonds et al. 1989, Kalish 1990, Campana \& Gagné 1994). While otoliths are well known for the formation of the annual (Casselman 1987) and daily growth rings (Pannella 1971, Campana \& Neilson 1985) used in their age determination, it is their elemental composition which has recently attracted attention as a potential means to track and identify fish populations. The potential is based on 2 observations: (1) otoliths grow throughout the life of the fish, and unlike bone, are metabolically inert (Campana \& Neilson 1985); once deposited, otolith material is unlikely to be resorbed or altered; and (2) the calcium carbonate and trace elements that make up $90 \%$ of the otolith appear to be mainly derived from the water (Simkiss 1974, Campana unpubl.), as modified by ambient temperature. Accordingly, the elemental composition of the otolith reflects that of the water in which the fish lives, although not necessarily in a simplistic fashion (Kalish 1989, Fowler et al. 1995). Since the physical and chemical characteristics of seawater vary from place to place (Johnson et al. 1992), fish populations occupying different water masses should contain otoliths with different exposure histories to the ocean environment, despite any periodic intermixing. The objective of this study was to test this hypothesis on adjacent cod Gadus morhua populations at a time of complete separation and then use the results to discriminate between the 2 populations during a time of mixing.

Various workers have reported sample-specific differences in elemental concentration in tissues other than otoliths, but the implications of their findings are somewhat unclear. Analyses of bone (Behrens Yamada et al. 1987), scales (Johnson 1989), and various soft tissues (Calaprice 1971. Hellou et al. 1992) must reflect composition during growth, but the signal is distorted by metabolic reworking after initial deposition as well as short-term changes due to effects such as starvation. 
As a result, assays of such tissues are not particularly appropriate for population discrimination. On the other hand, the acellular otolith is ideally suited as a storage site for trace elements after incorporation.

Site-specific differences in otolith elemental composition have been reported previously, but interpretation has generally been confounded by ontogenetic effects, assay limitations, and unexpected differences among samples (Papadopoulou et al. 1980, Edmonds et al. 1989, 1992, Grady et al. 1989, Gunn et al. 1992, Sie \& Thresher 1992, Campana \& Gagné 1994, Campana et al. 1994). It may be that the choice of elements, more than anything, has limited the value of these studies. For instance, most of the 6 minor elements detectable with the commonly used electron microprobe are under physiological control (Kalish 1989, Fowler et al. 1995) and, thus, are relatively poor indicators of population identity. A far larger suite of trace elements can be detected with inductively coupied plasma mass spectroscopy (ICPMS), but instrument artifacts and the relative purity of the fish otolith have limited past attempts to detect what are expected to be relatively smail differences dmong popuilations (Edrionds et al. 1992, Campana \& Gagné 1994). Yet it is these trace elements which appear to be least regulated during uptake and, therefore, most reflective of the environment (Fowler et al. 1995). For this reason, we decided to adopt the use of isotope dilution ICPMS (ID-ICPMS) for our assays, to take advantage of its reputation for extreme accuracy, precision and sensitivity (Fassett \& Paulsen 1989).

\section{MATERIALS AND METHODS}

The timing of sample collection was designed in light of the annual winter migration of cod from the southern Gulf of St. Lawrence (NAFO Division 4T) onto the area of the Scotian Shelf occupied by the NAFO Division 4VsW cod stock (Fig. 1) (Hanson \& Nielsen 1992). Reference samples of Gulf cod were collected by fisheries observers in June (Table 1), which is around the time of spawning, and a time when no other cod stocks are known to be in the southern Gulf (Templeman 1962). Reference samples of Scotian Shelf cod were sampled in 2 consecutive years (1992 and 1993); in each year samples were taken in mid-late summer, when the shelf is presumed to be clear of all other stocks. Peak stock mixing is believed to occur in late winter (Templeman 1962), which is when our samples of unknown stock identity were collected from the Scotian Shelf. All cod samples were drawn from several independent collections at each site in each year, and all were restricted to sexually mature fish between the lengths of 44 to $85 \mathrm{~cm}$. Immediately after capture, sagittal otoliths were removed from each fish, cleansed of adhering tissue, and stored dry in paper envelopes until they could be examined further. In preparation for IDICPMS, otoliths were decontaminated in a Class 100 clean room (Campana \& Gagné 1994), weighed to the nearest $\mathrm{mg}$, dissolved in $5 \mathrm{ml}$ sub-boiling distilled nitric acid, and brought to $250 \mathrm{ml}$ with Super-Q water. Enriched isotopic spikes for all elements were added

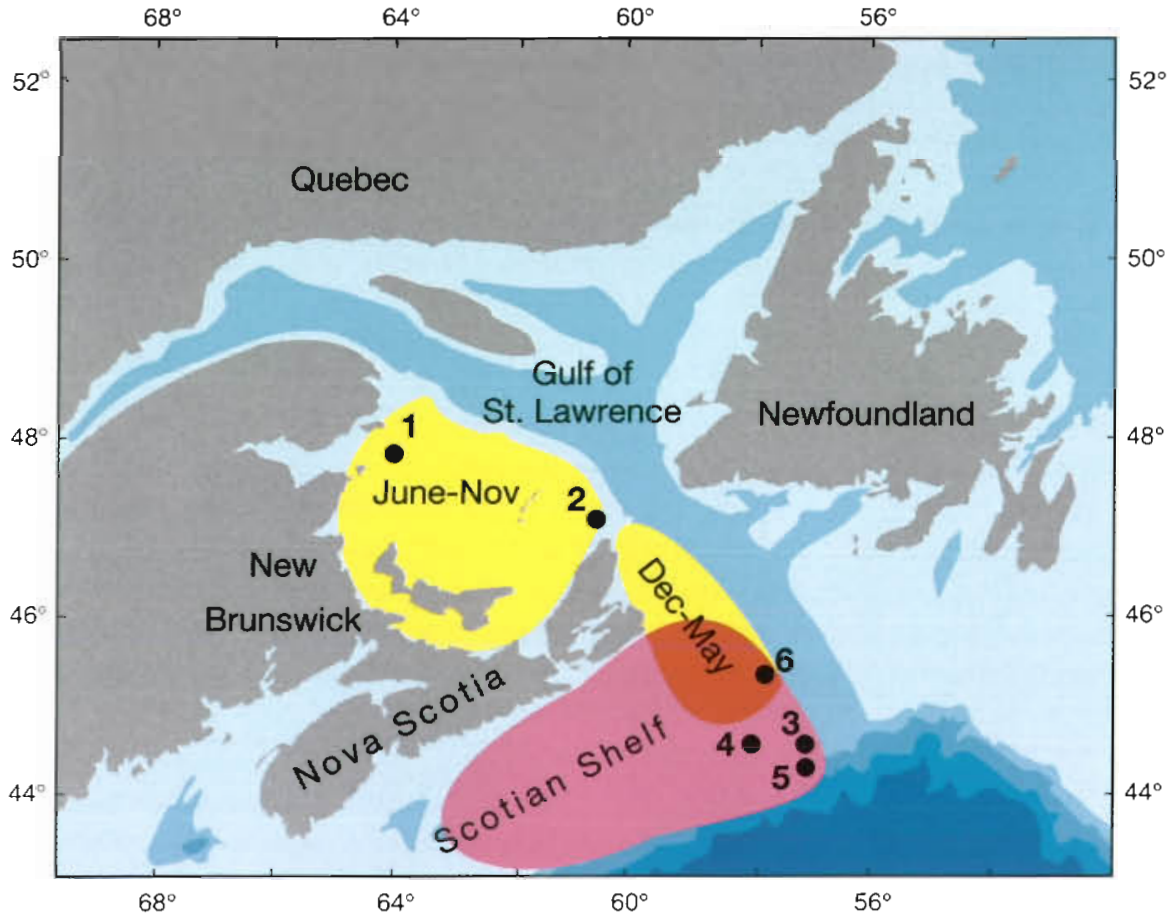

Fig. 1. Gadus morhua. Principal residence grounds and overwintering grounds for two of the major cod stocks off of the eastern coast of Canada. Cod in the southern Gulf of St. Lawrence (yellow) overwinter and mix with Scotian Shelf cod (red) through the period December to May. Numbered sampling sites correspond to those listed in Table 1 
Table 1. Gadus morhua. Sample collection information. Each sample represents several independent collections made within a $5 \mathrm{~km}$ radius. Sample locations are mapped in Fig. 1

\begin{tabular}{|clccc|}
\hline $\begin{array}{c}\text { Sample } \\
\text { no. }\end{array}$ & Location & Date & $\begin{array}{c}\text { Fish length } \\
\left.\text { (mean } \pm \mathrm{SE}_{\mathrm{r}} \mathrm{cm}\right)\end{array}$ & $\begin{array}{c}\text { Otolith weight } \\
\text { (mean } \pm \mathrm{SE}, \mathrm{g})\end{array}$ \\
\hline 1 & Western Gulf & Jun 1992 & $52.2 \pm 1.0$ & $0.40 \pm 0.02$ \\
2 & Eastern Gulf & Jun 1992 & $53.7 \pm 1.1$ & $0.40 \pm 0.01$ \\
3 & Scotian Shelf & Aug 1993 & $57.1 \pm 1.4$ & $0.39 \pm 0.02$ \\
4 & Scotian Shelf & Jul 1992 & $53.3 \pm 1.2$ & $0.36 \pm 0.02$ \\
5 & Scotian Shelf & Mar 1993 & $55.1 \pm 1.4$ & $0.38 \pm 0.02$ \\
6 & Scotian Shelf & Feb 1992 & $59.6 \pm 1.5$ & $0.44 \pm 0.02$ \\
\hline
\end{tabular}

fingerprints represented a sample site and not just a school of fish.

Our primary interest was in the differentiation of the western Gulf cod stock (Sample 1) from that of the Scotian Shelf (Samples 3 and 4), since these 2 stocks represent the main aggregations of cod off the southeastern coast of Canada. Cod from the eastern Gulf (Sample 2) form a smaller, more localized aggregation, with unknown affinities to the western Gulf cod (Templeman 1962). Using principal component analysis (PCA) to describe the

to each otolith prior to acid dissolution, except for $\mathrm{Sr}$ and $\mathrm{Mg}$ which were added after digestion. The assay sequence was systematically mixed by sample site to avoid the possibility of instrument drift (Campana \& Gagné 1994), although none was later observed.

\section{RESULTS}

Of the 28 elements known to be present in the otolith (Campana \& Gagné 1994), 6 elements featured the multiple isotopes free of spectral interferences which are required by ID-ICPMS. Detection limits ( $3 \sigma$ in ppm per otolith weight) for $\mathrm{Li}(0.007), \mathrm{Mg}(0.05), \mathrm{Zn}(0.05)$, Sr $(0.12)$, and $\mathrm{Ba}(0.004)$ were all well below observed concentrations in the otolith; that for $\mathrm{Pb}(0.007)$ was not significantly less than $44 \%$ of the observations. Coefficients of variation for replicate assays were less than $3 \%$ for all elements except $\mathrm{Pb}$, which was $8 \%, \mathrm{Mg}, \mathrm{Pb}$ and $\mathrm{Zn}$ were heteroscedastic and thus were transformed ( $\mathrm{n}, \mathrm{ln}$ and square root, respectively) prior to analysis. Three of the elements ( $\mathrm{Li}, \mathrm{Mg}$, and $\mathrm{Sr}$ ) showed small but statistically significant relationships with otolith weight (ANCOVA, $\mathrm{p}<0.05)_{;} \mathrm{Li}$ and $\mathrm{Mg}$ were negatively related to otolith weight, while $\mathrm{Sr}$ showed a positive relationship. The effect of otolith weight was subsequently removed using the common within-group slope, although this procedure did not modify any of the results; all subsequent statistical analyses were repeated using both detrended and undetrended data, and in all cases, the conclusions were identical. The same results were observed if the analysis was restricted to otoliths in the range 0.35 to $0.45 \mathrm{~g}$ without detrending.

All 6 of the elements differed significantly among sample sites (ANOVA, $p<0.05$ ) (Table 2); inter-site differences were even more pronounced when analyzed as a multivariate fingerprint, rather than as individual elements (MANOVA, $\mathrm{p}<0.001$ ). On the other hand, the elemental fingerprints within sites, drawn from multiple independent collections within a given year, were not significantly different. Thus, the elemental elemental fingerprint, discrimination between the Scotian Shelf and western Gulf cod was virtually complete (Fig. 2A) (Table 3). Stepwise discriminant analy-
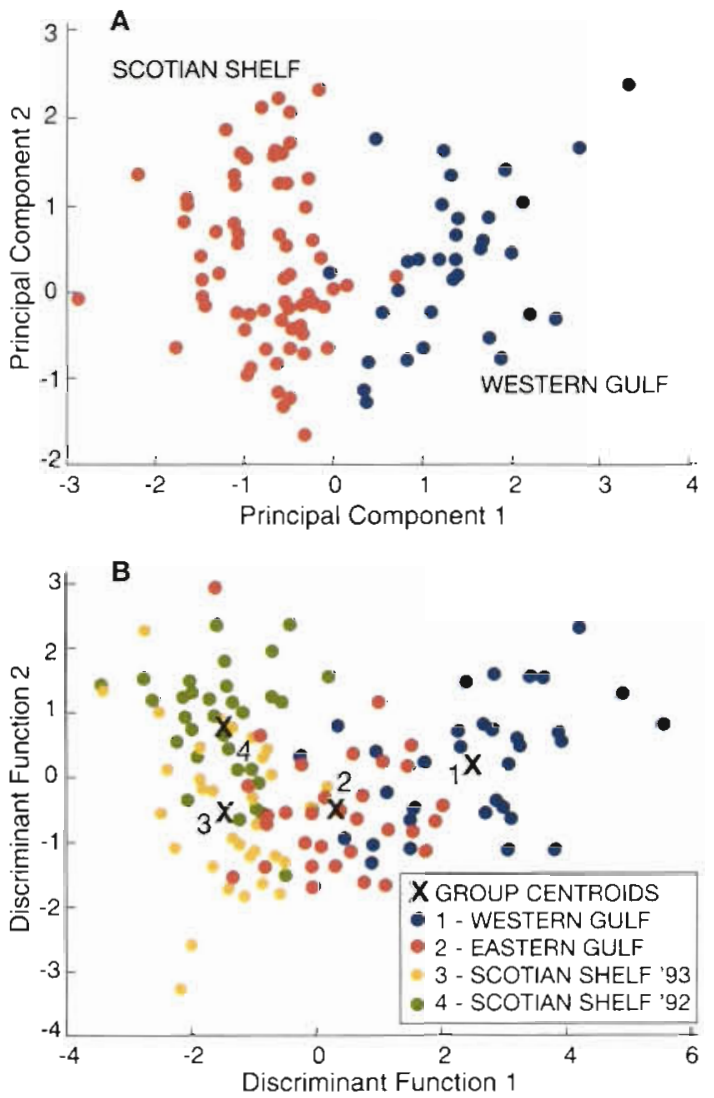

Fig. 2. Gadus morhua. Elemental fingerprints characteristic of cod otoliths from the southern Gulf of St. Lawrence and eastern Scotian Shelf. (A) Plot of the first 2 principal components corresponding to cod from the western Gulf (Sample 1) and Scotian Shelf (Samples 3 and 4). (B) Plot of the first 2 discriminant functions for each of the 4 reference samples. Separation of the western Gulf and Scotian Shelf samples is virtually complete (Table 3), but the sample from the eastern Gulf lies in between the two, albeit with significant separation from both. The first discriminant axis corresponds to an environmental gradient, while the second axis corresponds to a year effect 
Table 2. Gadus morhua. Elemental concentrations (mean $\pm \mathrm{SE}$, in $\mathrm{ppm}$ ) in otoliths collected from each of the 6 sample sites, before adjustment for otolith weight effects ( $\mathrm{n}=33$ for each site, except for Site 5 where $n=31$ )

\begin{tabular}{|ccccccc|}
\hline Sample site & $\mathrm{Ba}$ & $\mathrm{Li}$ & $\mathrm{Mg}$ & $\mathrm{Pb}$ & $\mathrm{Sr}$ & $\mathrm{Zn}$ \\
\hline 1 & $3.72 \pm 0.13$ & $0.61 \pm 0.02$ & $13.6 \pm 0.5$ & $0.0105 \pm 0.0014$ & $3394 \pm 82$ & $1.75 \pm 0.18$ \\
2 & $3.49 \pm 0.25$ & $0.55 \pm 0.03$ & $16.9 \pm 0.9$ & $0.0106 \pm 0.0021$ & $2969 \pm 80$ & $0.58 \pm 0.06$ \\
3 & $4.59 \pm 0.24$ & $0.56 \pm 0.03$ & $18.6 \pm 1.4$ & $0.0107 \pm 0.0014$ & $2541 \pm 46$ & $0.33 \pm 0.02$ \\
4 & $5.40 \pm 0.28$ & $0.42 \pm 0.02$ & $17.0 \pm 0.5$ & $0.0155 \pm 0.0016$ & $2621 \pm 53$ & $0.44 \pm 0.04$ \\
5 & $3.85 \pm 0.19$ & $0.65 \pm 0.04$ & $15.8 \pm 0.4$ & $0.0090 \pm 0.0013$ & $2865 \pm 56$ & $0.49 \pm 0.04$ \\
6 & $3.52 \pm 0.17$ & $0.60 \pm 0.07$ & $16.1 \pm 1.1$ & $0.0094 \pm 0.0010$ & $2864 \pm 82$ & $0.31 \pm 0.02$ \\
\hline
\end{tabular}

sis of all 4 reference sample sites (Sample Sites 1 to 4 ) resulted in a pattern of discrimination for the 2 major cod stocks similar to that of the PCA, with highly significant inter-site differences $(p<0.001)$. The elemental fingerprint of the sample from the eastern Gulf (Sample 2) was significantly different from both the western Gulf sample and those from the Scotian Sheif ( $p<0.01$ ), but lay in between the two in discriminant space (Fig. 2B). The 2 sample collection years from the eastern Scotian Shelf (Sample Sites 3 and 4) also difiered signiricantì. Discrimination among all sites wâs based on 4 elements, with $\mathrm{Zn}$ and $\mathrm{Sr}$, and $\mathrm{Li}$ and $\mathrm{Ba}$, being the major contributors to the first and second discriminant function, respectively. Virtually all of the explained variance was accounted for by the first 2 discriminant functions ( 88 and $10 \%$, respectively), with the stock discrimination resulting from separation along the first discriminant axis and the second axis serving to differentiate between the different years of sample collection (Fig. 2B). Since temperature and salinity both increase between the Gulf of St. Lawrence and the Scotian Shelf, the first discriminant axis appeared to correspond to an environmental gradient.

Using the discriminant functions developed from the reference samples (Samples 1 to 4), Samples 5 and 6 from the winter Scotian Shelf fishery were classified as to most likely sample site origin. Less than $7 \%$ of either sample was classified as being from the western Gulf

Table 3. Gadus morhua. Jack-knifed classification accuracy of cod samples identified through discriminant function analyses of otolith elemental fingerprints. Samples 5 and 6 comprised fish of unknown origin collected during the winter fishery for cod on the Scotian Shelf

\begin{tabular}{|lcrrrrr|}
\hline $\begin{array}{l}\text { Actual group } \\
\text { (sample no. and location) }\end{array}$ & No. of & \multicolumn{4}{c}{ Predicted group membership (\%) } \\
& cases & 1 & 2 & 3 & 4 \\
\hline 1 & Western Gulf & 33 & 70 & 30 & 0 & 0 \\
2 & Eastern Gulf & 33 & 18 & 61 & 12 & 9 \\
3 & Scotian Shelf (1993) & 33 & 0 & 9 & 64 & 27 \\
4 & Scotian Shelf (1992) & 33 & 0 & 9 & 21 & 70 \\
5 & Unknown & 31 & 6 & 65 & 23 & 6 \\
6 & Unknown & 33 & 3 & 33 & 33 & 30 \\
\hline
\end{tabular}

(Table 3). However, 33 to $65 \%$ of each sample was identified as being from the eastern Gulf, the remainder being from the Scotian Shelf (Table 3). When plotted in the same discriminant space as the reference samples, both of the unknown samples were characterized by distributions in keeping with an eastern Gulf Scotian Shelf mixture.

\section{DISCUSSION}

The otolith elemental fingerprints associated with the western Gulf and eastern Scotian Shelf cod stocks were sufficiently distinct to serve as natural tags in monitoring their relative distribution and are among the most powerful stock discriminators yet reported for these stocks. Such complete discrimination between adjacent cod stocks is unusual, whether based on morphometric (Templeman 1962) or genetic (Mork et al. 1985, Smith et al. 1989) indicators. Cod are known to spawn on dozens of offshore banks and in many coastal regions throughout the NW Atlantic, with each spawning aggregation assumed to represent a distinct population (Templeman 1962). However, cod are highly migratory and many populations intermix at times other than spawning (Templeman 1962, Wise 1963, McKenzie 1956). Since even anadromous fish like salmon are known to stray to alternate spawning sites at rates of up to $40 \% \mathrm{yr}^{-1}$ (Quinn 1993), it is not surprising that gene mixing rates and other factors have confounded past attempts at distinguishing among stocks. Elemental fingerprints are not genetic markers and cannot be used to distinguish among populations in terms of genetic differences. However, our results indicate that elemental fingerprints can discriminate between aggregations of fish which have lived the greater part of their lives in separate water masses, thus complementing information available from DNA fingerprints. Both temperature and salinity are known modifiers of otolith elemental 
composition (Fowler et al. 1995). Thus, the observed discrimination was consistent with expectations based on the response of otolith trace element composition to the ambient environment (Fowler et al. 1995). In the current study, the difference in temperature and salinity between the western Gulf and the eastern Scotian Shelf was sufficiently large (approximately $2^{\circ} \mathrm{C}$ and $3 \%$ ) to enhance the potential for stock separation based on elemental fingerprints.

Elemental fingerprints of whole dissolved otoliths represent the lifelong integration of an individual fish's exposure to the environment. Thus the modest observed difference between the 1992 and 1993 eastern Scotian Shelf samples was expected based on their slightly different exposure history to the environment. However, they are not sensitive to short-term effects. This point was highlighted by the similarity of the multiple independent samples used to characterize each sample site. Fingerprints based on the commonly assayed otolith elements such as $\mathrm{Na}, \mathrm{K}, \mathrm{S}$, and $\mathrm{Cl}$ have not always shown such within-site consistency (Edmonds et al. 1992, Gunn et al. 1992, Thresher et al. 1994), presumably due to physiological regulation (Kalish 1989, 1990, Sie \& Thresher 1992). Thus, the fact that samples from the western and eastern Gulf of St. Lawrence had very different fingerprints indicates that the 2 groups of fish lived apart throughout much of their 6 to 10 yr lifetime (Hanson \& Nielsen 1992). While segregation such as this does not necessarily imply that the 2 groups constitute separate stocks, it does point to a significant heterogeneity within the Gulf. Studies based on morphometrics, meristics and tag returns have also suggested that eastern Gulf cod are more closely allied with fish off the northeastern coast of Nova Scotia than with the western Gulf fish with which they are now managed (Templeman 1962, Martin \& Jean 1964).

Fishermen have long been aware of the 'river of fish' which exits the Gulf of St. Lawrence each fall to overwinter with the resident stock on the Scotian Shelf edge. However, fishing effort on the overwintering cod has increased substantially in the past $5 \mathrm{yr}$ as cod abundance in the northwest Atlantic has plummeted (FRCC 1993). By taking advantage of the difference in size at age of the 2 cod stocks, Hanson \& Nielsen (1992) used Kimura-Chikuni analysis of length-frequency mixtures to conclude that the majority of the Gulf cod migrated no further than the location indicated by Sample 6. Our findings that western Gulf cod were minimally represented in the mixed fishery samples was in keeping with Hanson \& Nielsen's (1992) conclusions. However, 33 to $65 \%$ of each sample was identified as being from the eastern Gulf, the remainder being Scotian Shelf fish. There are 2 possible explanations for these somewhat unexpected results: (1) Cod migration out of the Gulf is not targeted at a common site as it is in many pelagic fishes and birds (Quinn \& Brodeur 1991), but rather the extent of migration is limited on an individual basis by energetic considerations. This would imply that eastern Gulf cod would migrate considerably further out along the Shelf than would those from the western Gulf. Hanson \& Neilsen's inability to identify the former (Hanson \& Nielsen 1992) would then stem from the relatively small representation of eastern Gulf cod in their reference Gulf cod sample. (2) The cod in Samples 5 and 6 classified as being from the eastern Gulf were misclassified and actually originated off the northeastern tip of Nova Scotia. Given the proximity and similar environmental conditions of the latter to the eastern Gulf shore, it is unlikely that cod living in the 2 locations could be differentiated using otolith elemental fingerprints. However, under either of the above scenarios, the net effect is the same: a significant proportion of the cod caught on the northeastern Scotian Shelf in winter were not of Scotian Shelf origin. Using otolith elemental fingerprints as markers in individual fish, it should now be possible to track the population movements of this and other fish species, thus addressing one of the central problems in fisheries management and studies of fish populations.

Acknowledgements. We thank Joanne Hamel, Brad Methven, John Dalziel, Art Cosgrove, Mark Hanson, and Ghislain Chouinard for their assistance and advice on this project. Simon Thorrold, Mike Sinclair, John Casselman, Tony Fowler, Cynthia Jones, David Secor and an anonymous reviewer provided helpful comments on the manuscript.

\section{LITERATURE CITED}

Behrens Yamada S, Mulligan TJ, Fournier D (1987) Role of environment and stock on the elemental composition of sockeye salmon (Oncorhynchus nerka) vertebrae. Can J Fish Aquat Sci 44:1206-1212

Calaprice JR (1971) X-ray spectrometric and multivariate analysis of sockeye salmon (Oncorhynchus nerka) from different geographic regions. J Fish Res Bd Can 28: $369-377$

Campana SE, Fowler AJ, Jones CM (1994) Otolith elemental fingerprinting for stock identification of Atlantic cod (Gadus morhua) using laser ablation ICPMS. Can J Fish Aquat Sci 51:1942-1950

Campana SE, Gagne JA (1994) Cod stock discrimination using ICPMS elemental assays of otoliths. In: Secor DH, Dean JM, Campana SE (eds) New developments in fish otolith research. University of South Carolina Press, Columbia (in press)

Campana SE, Neilson JD (1985) Microstructure of fish otoliths. Can J Fish Aquat Sci 42:1014-1032

Casselman JM (1987) Determination of age and growth. In: Weatherley $\mathrm{AH}$, Gill HS (eds) The biology of fish growth, Chap 7. Academic Press, New York, p 209-242 
Edmonds JS, Moran MJ, Caputi N, Morita M (1989) Trace element analysis of fish sagittae as an aid to stock identification: pink snapper (Chrysophrys auratus) in Western Australia waters. Can J Fish Aquat Sci 46:50-54

Edmonds JS, Lenanton RCJ, Caputi N, Morita M (1992) Trace elements in the otoliths of yellow-eye mullet (Aldrichetta forsteri) as an aid to stock identification. Fish Res 13:39-51

Fassett JD, Paulsen PJ (1989) Isotope dilution mass spectrometry for accurate elemental analysis. Analyt Chem 61: 643A-649A

Fowler AJ, Campana SE, Jones CM, Thorrold SR (1995) Experimental assessment of the effect of temperature and salinity on elemental composition of otoliths using solution-based ICPMS. Can J Fish Aquat Sci (in press)

FRCC (1993) Conservation requirements for Atlantic groundfish: report to the Minister of Fisheries and Oceans. Fisheries Resource Conservation Council, Ottawa

Grady JR, Johnson AG, Sanders M (1989) Heavy metal content in otoliths of king mackerel (Scomberomorus cavalla) in relation to body length and age. Contr mar Sci 31 $17-23$

Gunn JS, Harrowfield IR, Proctor CH, Thresher RE (1992) Electron probe microanalysis of fish otoliths - evaluation of techniques for studying age and stock discrimination $\mathrm{J}$ exp mar Biol Ecol 158:1-36

Hanson JM, Nielsen GA (1992) Catches of 4T-Vn (Jan-Apr) cod in the 4Vs winter fishery, 1980-1992. CAFSAC Res Doc $92 / 5 \mathrm{i}$

Hellou J, Warren WG, Payne JF, Belkhode S, Lobel P (1992) Heavy metals and other elements in three tissues of cod, Gadus morhua from the Northwest Atlantic. Mar Pollut Bull 24:452-458

Johnson KS, Coale KH, Jannasch HW (1992) Analytical chemistry in oceanography. Analyt Chem 64:1065-1075

Johnson MG (1989) Metals in fish scales collected in Lake Opeongo, Canada from 1939 to 1979. Trans Am Fish Soc 118:331-335

Kalish JM (1989) Otolith microchemistry: validation of the effects of physiology, age and environment on otolith composition. J exp mar Biol Ecol 132:151-178

This article was submitted to the editor
Kalish JM (1990) Use of otolith microchemistry to distinguish the progeny of sympatric anadromous and non-anadromous salmonids. Fish Bull US 88:657-666

Martin WR, Jean Y (1964) Winter cod taggings off Cape Breton and on offshore Nova Scotia banks, 1959-1962. J Fish Res Bd Can 21:215-238

McKenzie RA (1956) Atlantic cod tagging off the Southern Canadian mainland. Bull Fish Res Bd Can 105:1-93

Mork J, Ryman N, Ståhl G, Utter F, Sundnes G (1985) Genetic variation in Atlantic cod (Gadus morhua) throughout its range. Can J Fish Aquat Sci 42:1580-1587

Pannella G (1971) Fish otoliths: daily growth layers and periodical patterns. Science 173:1124-1127

Papadopoulou C, Kanias GD, Kassimati E (1980) Trace element content in fish otoliths in relation to age and size. Mar Pollut Bull 11:68-72

Quinn TP (1993) A review of homing and straying of wild and hatchery-produced salmon. Fish Res 18:29-44

Quinn TP, Brodeur RD (1991) Intra-specific variations in the movement patterns of marine animals. Am Zool 31: 231-241

Sie SH, Thresher RE (1992) Micro-PIXE analysis of fish otoliths: methodology and evaluation of first results for stock discrimination. Int J PIXE 2:357-379

Simkiss K (1974) Calcium metabolism of fish in relation to ageing. In: Bagenal TB (ed) The ageing of fish. Unwin Brothers Ltd, Old Woking, p 1-12

Sinith PJ, Birley AJ, Jamicson A, Bishop CA (1980) Mitochondrial DNA in the Atlantic cod, Gadus morhua: lack of genetic divergence between eastern and western populations. J Fish Biol 34:369-373

Templeman W (1962) Divisions of cod stocks in the Northwest Atlantic. ICNAF Redbook III:79-123

Thresher RE, Proctor $\mathrm{CH}$, Gunn JS, Harrowfield IR (1994) An evaluation of electron probe microanalysis of otoliths for stock delineation and identification of nursery areas in a southern temperate groundfish, Nemadactylus macropterus (Cheilodactylidae). Fish Bull US 92:817-840

Wise JP (1963) Cod groups in the New England area. Fish Bull US 63:189-203

Manuscript first received: October 14, 1994

Revised version accepted: March 8, 1995 